\title{
Growth and Development of Honey Weed Based on Days or Thermal UNITS ${ }^{1}$
}

\author{
Crescimento e Desenvolvimento de Rubim com Base em Dias ou Unidades Térmicas
}

\author{
SILVA, A.P.P. ${ }^{2}$, MARQUES, B.S. ${ }^{2}$, LIMA, R.S.O. ${ }^{2}$, MACHADO, E.C.R. ${ }^{2}$, GONÇALVES, M.F. ${ }^{2}$, and \\ CARVALHO, S.J.P. ${ }^{2}$
}

\begin{abstract}
This work was carried out with the objective of evaluating the growth and development of honey weed (Leonurus sibiricus) based on days or thermal units (growing degree days). Thus, two independent trials were developed to quantify the phenological development and total dry mass accumulation in increasing or decreasing photoperiod conditions. Considering only one growing season, honey weed phenological development was perfectly fit to day scale or growing degree days, but with no equivalence between seasons, with the plants developing faster at increasing photoperiods, and flowering 100 days after seeding. Even day-time scale or thermal units were not able to estimate general honey weed phenology during the different seasons of the year. In any growing condition, honey weed plants were able to accumulate a total dry mass of over $50 \mathrm{~g}$ per plant. Dry mass accumulation was adequately fit to the growing degree days, with highlights to a base temperature of $10{ }^{\circ} \mathrm{C}$. Therefore, a higher environmental influence on species phenology and a lower environmental influence on growth (dry mass) were observed, showing thereby that other variables, such as the photoperiod, may potentially complement the mathematical models.
\end{abstract}

Keywords: Leonurus sibiricus, growing degree days, phenology, dry mass, biology

RESUMO - Este trabalho foi desenvolvido com o objetivo de avaliar o crescimento e o desenvolvimento do rubim (Leonurus sibiricus) com base em dias ou unidades térmicas (graus dia). Para isso, dois experimentos independentes foram desenvolvidos, quantificando-se o desenvolvimento fenológico e o acúmulo de massa seca total, em condição de fotoperiodo crescente ou decrescente. Considerando apenas uma estação de crescimento, obteve-se adequado ajuste do desenvolvimento fenológico do rubim às escalas em dias ou unidades térmicas acumuladas, porém sem equivalência entre as estações. As plantas se desenvolveram mais rapidamente em fotoperiodo crescente, com florescimento 100 dias após semeadura. Tanto a contagem do tempo em dias quanto as unidades térmicas não foram adequados estimadores da fenologia geral do rubim durante as diferentes estações do ano. Em qualquer condição de crescimento, as plantas de rubim acumularam massa seca total superior a $50 \mathrm{~g}$ por planta. O acúmulo de massa foi ajustado às unidades térmicas, com destaque para temperatura basal de $10^{\circ} \mathrm{C}$. Dessa forma, ressalta-se maior influência ambiental sobre a fenologia da espécie e menor sobre o crescimento (massa seca), em que outras variáveis podem, potencialmente, complementar os modelos matemáticos, incluindo o fotoperiodo.

Palavras-chave: Leonurus sibiricus, graus dia, fenologia, massa seca, biologia.

\section{INTRODUCTION}

Weeds are one of the main biotic components of the agroecosystem that are able to negatively interfere in crops. The negative effects caused by these plants manifest on the agricultural production quantity and quality, as a consequence of the competition for the growth resources offered by the environment, of the allelopathy, or for being the host of pests

Recebido para publicação em 25.9.2013 e aprovado em 18.2.2014.

Instituto Federal do Sul de Minas Gerais, Machado-MG, Brasil, <alanpratezipenhasilva@yahoo.com.br>.

Planta Daninha, Viçosa-MG, v. 32, n. 1, p. 81-89, 2014 
and diseases. Lorenzi (2006) estimates that, in Brazil, the agricultural losses caused by the interference of weeds total approx. 20-30\%.

Thus, knowing the biological characteristics of weeds is an advantage when deciding how and when chemical intervention should be used. The development of plants is related with several phenological stages, presenting greater or limited sensibility to the application of herbicides (Dias et al., 2013). After having emerged, these plants quickly dominate the environment, either by the development of a vigorous root system or by taking over the available space with the greatest light interception (Horak \& Loughin, 2000; Carvalho et al., 2008). The post emergence control will become more difficult and the competition damage will be larger whenever they are better established in the environment, or the root system is strong, and even when the number of leaves is large.

Among the most common weed plants found in agricultural areas, especially in coffee plantations, the honey weed (Leonurus sibiricus) stands out (Ferreira et al., 2011). It belongs to the Lamiaceae family, and it is annual or biannual, upward, aromatic, ramified, herbaceous, or sub shrubby, $40-120 \mathrm{~cm}$ high, with propagation by seeds (Lorenzi, 2000). The Lamiaceae family comes mainly from countries of the Mediterranean and Middle East and consists of approx. 200 kinds and 3,200 species. In Brazil, it is found in virtually all regions (Kissmann \& Groth, 2000). The Leonurus genus also includes several representatives of therapeutic use (Duarte \& Ferreira Lopes, 2005).

Regarding the competition, Ronchi et al. (2003) observed that the honey weed and other species of weeds caused a loss in the nutrient content of coffee plants, even in lower densities. Besides the interspecific competition, between coffee and honey weed, there is also the intraspecific competition, between individuals of the weed species (Ronchi et al., 2003). Ferreira et al. (2011) noted that, in the second year of transition to organic coffee, honey weed was the most prevalent farming species, with a high relative density and abundance.
In this sense, studies about the growth and development of weeds provide information about different phenological stages and vegetal growth standards. These results enable the behavior analysis of plants regarding ecological factors, as well their action over the environment, mainly regarding their interference with other plants, which may contribute to the development of integrated management systems (Lucchesi, 1984; Bianco et al., 1995).

Even though the importance of studies that evaluate the biology of weed plants is recognized, rather few studies discuss the growth and development of these species, and even fewer are based on accumulated growing degree days (thermal units). The prediction of different phenological aspects of crops, weeds, and other pests with simple thermal equations is an excellent tool to provide practical solutions to crop problems (Ghersa \& Holt, 1995). Thus, this study evaluated the growth and development of honey weed (Leonurus sibiricus) based on days or thermal units (growing degree days).

\section{MATERIALS AND METHODS}

Two independent trials were carried out in an experimental unit at Instituto Federal de Educação, Ciência e Tecnologia do Sul de Minas Gerais, campus Machado, MG, (21. 40' S; $45^{\circ} 55^{\prime} \mathrm{W} ; 850 \mathrm{~m}$ of altitude). In each trial, the growth and development of honey weed (Lonurus sibiricus) was evaluated. The first trial was developed between August and December 2012 (increasing photoperiod), and the second trial between February and July 2013 (decreasing photoperiod). The $L$. sibiricus seedlings were collected in agricultural and nonagricultural areas in the municipality of Machado. Later, the seeds were stored in paper bags, in a dry location, at ambient temperature until the beginning of the study.

The sowing was made in plastic pots with a $4 \mathrm{~L}$ capacity and filled with commercial substratum (Pinus skin + peat + vermiculite). After that, at the four-leaf stage, seedlings were relocated to the trial phase, also constituted by $4 \mathrm{~L}$ plastic pots, with a final density of one plant per pot. In this phase, pots were filled with a proportion of commercial substratum 
and vermiculite $(3: 1 ; \mathrm{v}: \mathrm{v})$ with the addition of complete commercial fertilizer. In addition to this, around 30 days after the relocation, there was a cover of fertilization with $630 \mathrm{mg}$ of $\mathrm{N}$ and $720 \mathrm{mg}$ of $\mathrm{S}$, when stages 32 and 25 were identified (Hess et al., 1997), for the first and second trials, respectively. The pots were irrigated as needed and, therefore, there was no dehydration.

After the seedlings' emergence, the phenology evaluation was conducted for the whole population, every three days, using the scale proposed by Hess et al. (1997). The phenological stage was defined when a certain development characteristic was found in $50 \%+1$ of the total remaining plants. In both trials, the experimental design that was used was randomized selection, with nine treatments (growth evaluations) and three replications. For each dry mass evaluation, three replications were randomly sampled by the destructive method and were washed in running water, so that the remaining substratum could be removed from the roots; following that, the material was dried in a greenhouse at $70{ }^{\circ} \mathrm{C}$ for 72 hours. After the drying process, the total dry mass of the plants (g per plant) was measured.

The trials were analyzed independently by means of the test $\mathrm{F}$ in the variance analysis. The phenological data of honey weed were adjusted to the counting period of days or thermal units (growing degree day-GD), by the linear regression model $y=a x$, where $y$ is related with the honey weed development in accordance with the phenological scale (Hess et al., 1997), $x$ refers to the scale used and $a$ is the model parameter. In practice, the parameter $a$ of this equation may be considered as the caloric units percentage effectively converted to units of vegetal phenology, enabling the calculation of the plants' development speed at a certain time of the year or on the sowing date.

To calculate the daily thermal units, the equation of Gilmore Jr. \& Rogers (1958) was used:

$$
G D=\left(\frac{T \max +T \min }{2}\right)-T b
$$

where: Tmax is the maximum daily temperature; Tmin is the minimum daily temperature; and $T b$ is the base temperature, evaluated at 10 or $15{ }^{\circ} \mathrm{C}$. the maximum and minimum daily temperatures were obtained at the weather station installed at campus Machado and were made available by the National Institute for Space Research - INPE (Figure 1).

The total dry mass was analyzed by means of nonlinear logistic regressions, also based on days or thermal units. The model proposed by Streibig (1988) was adopted:

$$
y=\frac{a}{\left[1+\left(\frac{x}{b}\right)^{c}\right]}
$$

where: $y$ is the response variable of interest, $x$ is the time scale (days or GD) and $a, b$, and $c$ are the equation estimate numbers ( $a$ is the range between the maximum and minimum point of the variable; $b$ corresponds to the time scale value that is necessary for the occurrence of $50 \%$ of variable response; and $c$ is the slope of the curve around $b$ ).

\section{RESULTS AND DISCUSSION}

Due to the events that may occur during vegetal development, there is a need to adopt numerical scales to define the levels for these periods. Traditionally, days have been used to count this time cycle; however, it is a variable that is subject to environmental interference that is indirectly expressed in the phenology. Thus, the temperature has been considered as the most important climate element to foresee physiological events, provided that there is no dehydration (Russelle et al., 1984; Gadioli et al., 2000).

The growing degree day method is based on the premise that a plant needs a given amount of energy, represented by the sum of thermal degrees needed for a certain phenological phase or even the full cycle to complete. It also admits a linear relationship between the temperature increase and the vegetal development (Gadioli et al., 2000). Therefore, it is possible to use mathematical models and simulations that adopt the concept of accumulated growing degree days (Medeiros et al., 2000).

Planta Daninha, Viçosa-MG, v. 32, n. 1, p. 81-89, 2014 


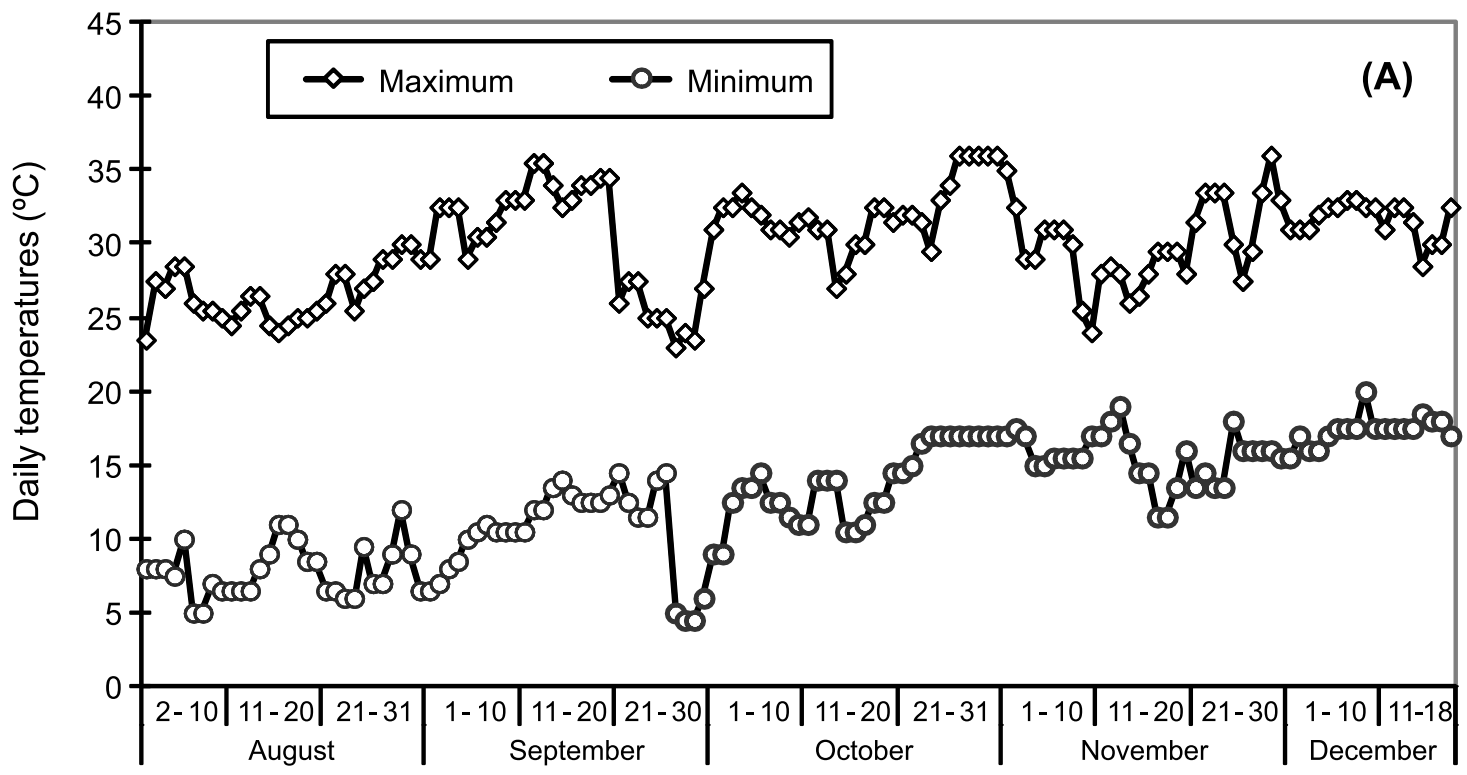

Months / Days (2012)

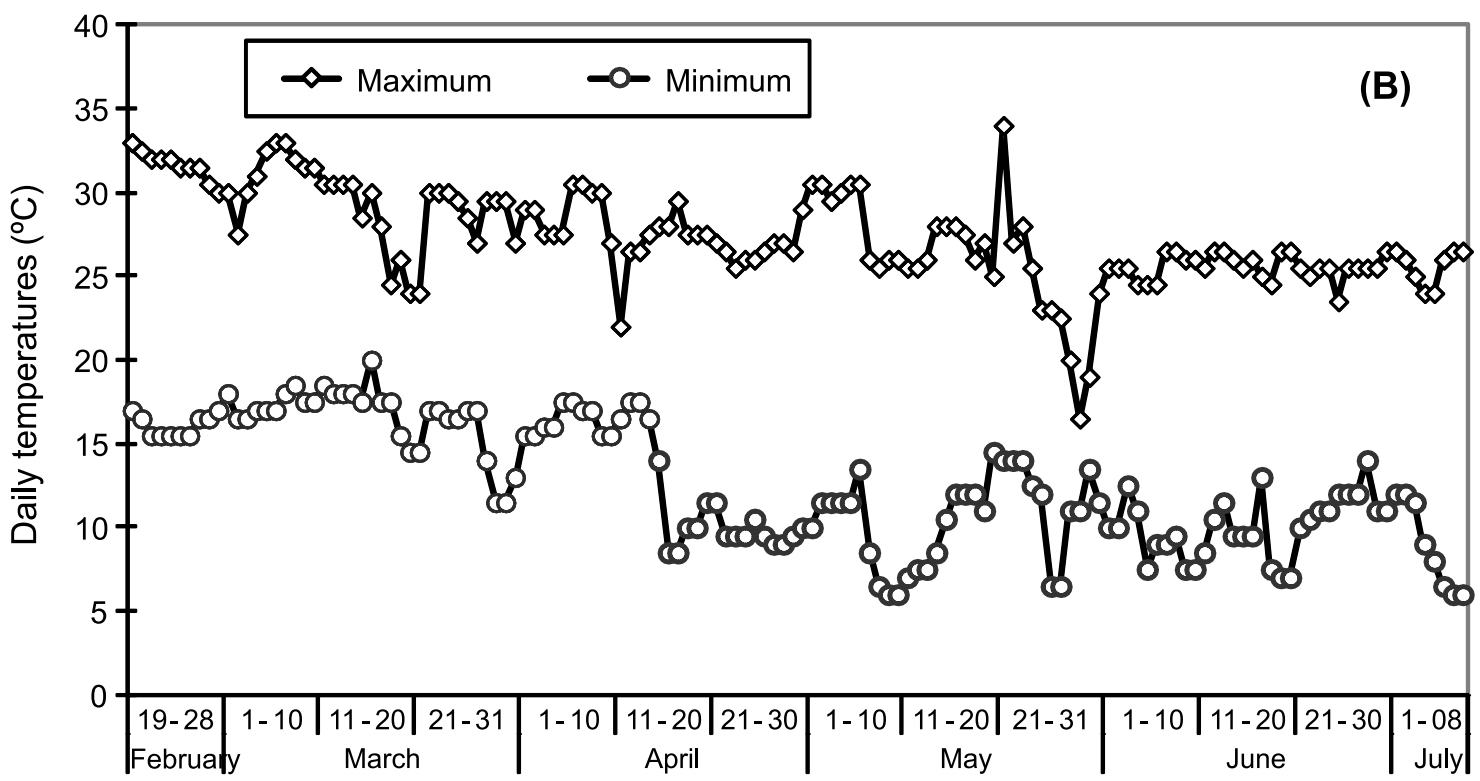

Months / Days (2013)

Figure 1 - Maximum and minimum daily temperatures for the trial development period and location. (A) second semester of 2012; (B) first semester of 2013. Machado, MG, 2013.

In this sense, there was an adequate adjustment of the honey weed's phenological development to the different scales used, in accumulated days or thermal units (GD), by means of the first degree linear equation, with determination coefficients always higher than
90\% (Table 1). No scale for the experiments developed in 2012 and 2013 was able to identify the confidence intervals overlap of parameter $a$ of the equation, in increasing and decreasing photoperiod conditions. For any time scale, the value $a$ obtained for the 
Table 1 - Scale adopted, mean squared residue of the model ${ }^{1 /}$ (QMres), test $\mathrm{F}$, determination coefficient ( $\left.\mathrm{R}^{2}\right)$, parameter $a$ of the equation and confidence interval (I.C.) with 5\% of relevance, for adjustment of the Leonurus sibiricus phenology to the accumulated thermal units (growing degree days), in all trial conditions. Machado, MG, 2013

\begin{tabular}{|c|c|c|c|c|c|c|c|c|}
\hline \multirow{2}{*}{ Photoperiod } & \multirow{2}{*}{ Year } & \multirow{2}{*}{ Scale } & \multirow{2}{*}{ QMres } & \multirow{2}{*}{$\mathrm{F}$} & \multirow{2}{*}{$\mathrm{R}^{2}$} & \multirow{2}{*}{$a$} & \multicolumn{2}{|c|}{ I.C. $(5 \%)$} \\
\hline & & & & & & & Minimum & Maximum \\
\hline \multirow{3}{*}{ Increasing } & \multirow{3}{*}{2012} & Days & 100.101 & $757.021 * *$ & 0.9284 & $0.5597^{*}$ & 0.5182 & 0.6012 \\
\hline & & $\mathrm{Tb} 10^{\circ} \mathrm{C}$ & 50.273 & $1538.061 * *$ & 0.9480 & $0.0538^{*}$ & 0.0510 & 0.0566 \\
\hline & & $\mathrm{Tb} 15^{\circ} \mathrm{C}$ & 27.665 & $2820.276^{* *}$ & 0.9569 & $0.1025^{*}$ & 0.0985 & 0.1064 \\
\hline \multirow{3}{*}{ Decreasing } & \multirow{3}{*}{2013} & Days & 13.395 & $1478.191 * *$ & 0.9423 & $0.3630^{*}$ & 0.3435 & 0.3825 \\
\hline & & $\mathrm{Tb} 10^{\circ} \mathrm{C}$ & 8.548 & $2330.011^{* *}$ & 0.9481 & $0.0326^{*}$ & 0.0312 & 0.0339 \\
\hline & & $\mathrm{Tb} 15^{\circ} \mathrm{C}$ & 15.089 & $1309.581 * *$ & 0.9403 & $0.0600^{*}$ & 0.0565 & 0.0634 \\
\hline
\end{tabular}

${ }^{1 /}$ Phenology $=a$. (growing degree days); $\mathrm{Tb}=$ base temperature; * Relevant by the test $\mathrm{t}$ with $5 \%$ of probability; ** Relevant with $1 \%$.

increasing photoperiod condition was higher than the one obtained for the decreasing photoperiod. That is, in increasing photoperiod condition, there was a larger conversion of the photosynthetically active temperature or radiation in the development stages, reaching a faster blooming and aging process. This conclusion indicates a different vegetal development (phenology) at different times of the year, when adjusted to the calculation in days or $\mathrm{GD}$, considering $\mathrm{Tb}=10$ or $15^{\circ} \mathrm{C}$ (Figure 2).

The base temperature - Tb is the minimum temperature for the growth of a certain species; any temperature under this will cause the growth to stop or suffer drastic reduction. The reference studies consider $\mathrm{Tb}=0{ }^{\circ} \mathrm{C}$ for weed plants and moderate climate crops, such as barley (Hordeum vulgare) and wheat (Triticum aestivum) (Cao \& Moss, 1989; Kirkby, 1995). Regarding sunflower (Helianthus annuus), Granier \& Tardieu (1998) found base temperatures around $4.8^{\circ} \mathrm{C}$.

For redroot pigweed (Amaranthus retroflexus), a species whose photosynthetic cycle type is $\mathrm{C}_{4}$, Gramig \& Stoltenberg (2007) registered $\mathrm{Tb}=8.5$. Base temperatures around $10^{\circ} \mathrm{C}$ have been registered for bean plant (Medeiros et al., 2000), corn (Gadioli et al., 2000) and switch grass Panicum virgatum (Sanderson \& Wolf, 1995). Villa Nova et al. (1999) used $\mathrm{Tb}=15$ for elephant grass (Pennisetum purpureum), notably a plant belonging to the Poaceae family of a tropical climate.

Vasconcelos et al. (2012) also reported a base temperature of $15^{\circ} \mathrm{C}$ for sour grass, in
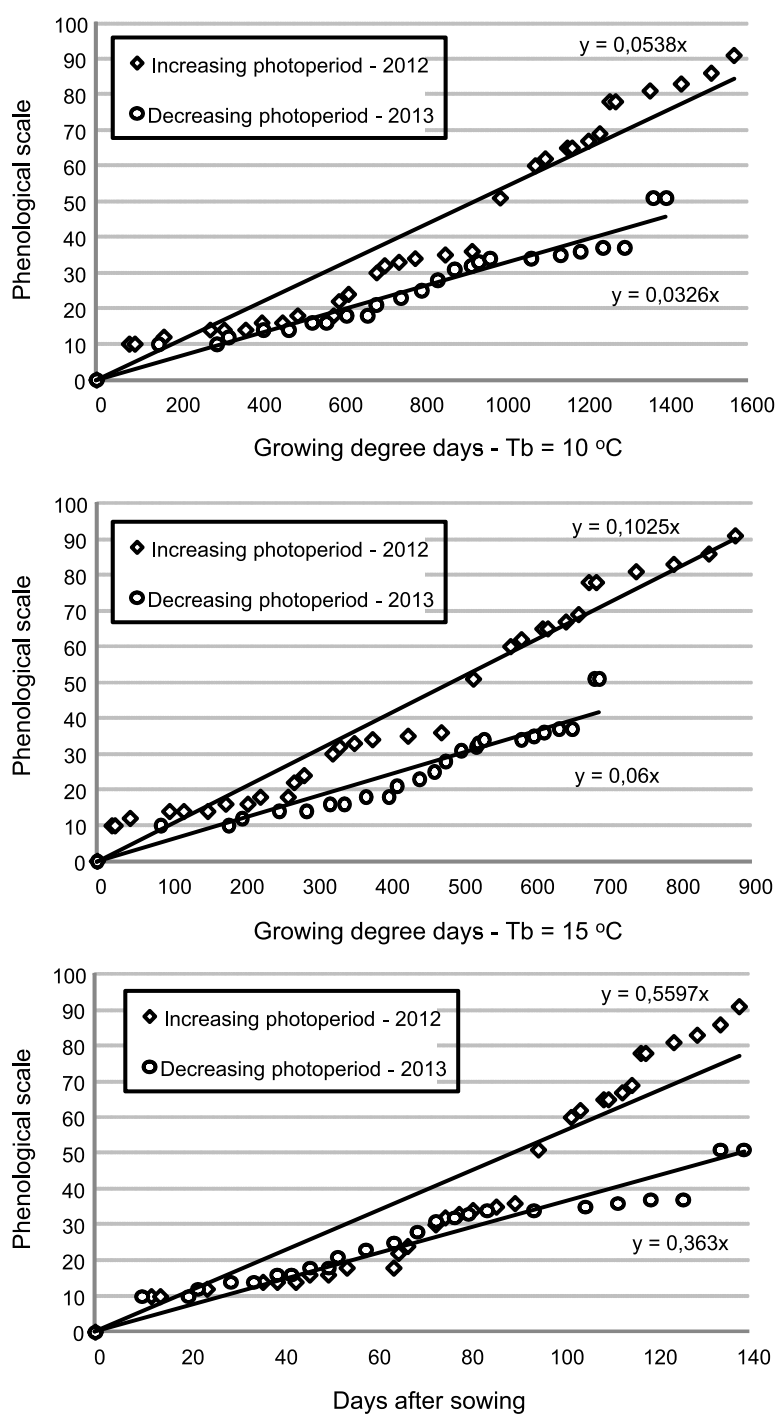

Figure 2 - Adjustment of the phenological development of honey weed (Leonurus sibiricus) to different scales, considering accumulated growing degree days, calculated with base temperature of 10 or $15^{\circ} \mathrm{C}$. Machado, MG, 2013.

Planta Daninha, Viçosa-MG, v. 32, n. 1, p. 81-89, 2014 
an experiment conducted with a decreasing photoperiod (January-July/2011). Therefore, considering the phenological development in the proposed scales and data consistency (Table 1), and considering the fact that honey weed is dicotyledonous with photosynthetic cycle type $\mathrm{C}_{3}$ and it is classified as an annual or biannual weed plant, the adequate base temperature, for future studies, is $\mathrm{Tb}=10^{\circ} \mathrm{C}$.

The ability to foresee the phenological stages of weed plants, such as blooming, development, and seed dispersal may be helpful for the creation of management measures (Ghersa \& Holt, 1995). In addition, the growth characteristics of a certain species are indicative of their competitive ability (Holt \& Orkutt, 1991). In an increasing photoperiod condition, the species blooming occurred 100 days after the sowing, with 1.079 or 569 $\mathrm{GD}$, for $\mathrm{Tb}=10$ or $15{ }^{\circ} \mathrm{C}$, respectively. In a decreasing photoperiod condition, 139 after the sowing there was only pre-blooming, with 1,401 or $691 \mathrm{GD}$, for $\mathrm{Tb}=10$ or $15^{\circ} \mathrm{C}$, respectively. It is possible to register, therefore, an adequate time between the emergence and blooming so that management measures can be taken before the seeds' dispersal.

Again, the differential phenological development of the species is characterized in different development conditions, whose blooming occurred more quickly in an increasing photoperiod condition. Coincidently, in 2013, the sowed plants were induced to blooming after the winter solstice (June), defining the beginning of an increase in the daily hours of insolation. At the moment of the solstice, the phenology identified was 37; days after, on $7 / 3 / 2013$, there was a pre-blooming. Even after a few days, this may be a strong indication of plant blooming boost whenever there is an occurrence of several days with increasing insolation. It is important to note that, among the ecological factors, the temperature effect is prominent and may affect the growth and productivity of different species of plants (McLanchlan et al., 1993; Guo \& Al-Khatib, 2003); however, the photoperiod effect may be crucial to the acceleration or slowing down of the plants' blooming.

The use of growth analyses is one of the easiest and more precise ways to infer the contribution of different physiological processes to the vegetal growth, enabling the acquaintance with the dynamics of plants' biomass production, distribution, and efficiency throughout the life cycle (Benincasa, 2004). In this sense, the total dry mass production is seen as a basic process of vegetal growth (Radosevich et al., 1997).

The total dry mass data were properly adjusted to the logistical model, with determination coefficients higher than 98\% (Table 2). A slow initial growth was identified for the species, with later exponential accumulation of dry mass after 45 days, with maximum values higher than $50 \mathrm{~g}$ per plant (Figure 3). Among the time scales used, a greater overlapping of curves was observed with the use of $\mathrm{Tb}=10^{\circ} \mathrm{C}$ (Figure 3); in this case, the adjustment was recalculated, using

Table 2 - Scale adopted, moment with blooming record, determination coefficient $\left(\mathrm{R}^{2}\right)$ of mode $\mathrm{l}^{\frac{1}{}}$ and parameters $a, b$, and $c$ of the logistic equation used to adjust the total dry mass of honey weed (Leonurus sibiricus), in all experimental conditions. Machado, MG, 2013

\begin{tabular}{|c|c|c|c|c|c|c|c|c|}
\hline \multirow{2}{*}{ Year } & \multirow{2}{*}{ Photoperiod } & \multirow{2}{*}{ Scale } & \multirow{2}{*}{ QM res } & \multirow{2}{*}{$\mathrm{F}$} & \multicolumn{3}{|c|}{ Model Parameters } & \multirow{2}{*}{$\mathrm{R}^{2}$} \\
\hline & & & & & $a$ & $b$ & $c$ & \\
\hline \multirow{3}{*}{2012} & \multirow{3}{*}{ Increasing } & Days & 0.923 & $2244.77 * *$ & 54.396 & 105.586 & -10.551 & 0.998 \\
\hline & & $\mathrm{Tb} 10^{\circ} \mathrm{C}$ & 1.101 & $1879.70 * *$ & 53.383 & 1113.467 & -9.268 & 0.998 \\
\hline & & $\mathrm{Tb} 15^{\circ} \mathrm{C}$ & 1.296 & $1596.96 * *$ & 52.781 & 586.088 & -8.444 & 0.998 \\
\hline \multirow{3}{*}{2013} & \multirow{3}{*}{ Decreasing } & Days & 6.723 & $314.784 * *$ & 91.316 & 123.503 & -4.622 & 0.989 \\
\hline & & $\mathrm{Tb} 10^{\circ} \mathrm{C}$ & 6.020 & $351.963 * *$ & 83.623 & 1247.107 & -7.025 & 0.990 \\
\hline & & $\mathrm{Tb} 15^{\circ} \mathrm{C}$ & 5.648 & $375.364 * *$ & 78.489 & 629.849 & -11.492 & 0.991 \\
\hline \multicolumn{2}{|r|}{ General } & $\mathrm{Tb} 10^{\circ} \mathrm{C}$ & 8,224 & $480.781^{* *}$ & 56.895 & 1126.041 & -9.593 & 0.984 \\
\hline
\end{tabular}

${ }^{1 /} \mathrm{y}=\mathrm{a} /\left(1+(\mathrm{x} / \mathrm{b})^{\mathrm{c}}\right) ; \mathrm{Tb}=$ base temperature; ** Relevance with $1 \%$ of probability. 
both of the growth conditions simultaneously (Table 2; Figure 4).

Thus, again, $\mathrm{Tb}=10^{\circ} \mathrm{C}$ for Leonurus sibiricus was properly used, considering the consistency of the adjustments obtained (Tables 1 and 2; Figure 3), as well as the characteristics related with the species biology. For the dry mass variable, analyzing both trials, with $\mathrm{Tb}=10{ }^{\circ} \mathrm{C}$, it is possible to highlight the capacity of the species to accumulate weight, higher than 50 g per plant;


Figure 3 - Accumulated total dry mass of honey weed (Leonurus sibiricus), in two different growing conditions, adjusted to different scales, considering accumulated growing degree days, calculated with base temperature of 10 or $15{ }^{\circ} \mathrm{C}$. Machado, MG, 2013.

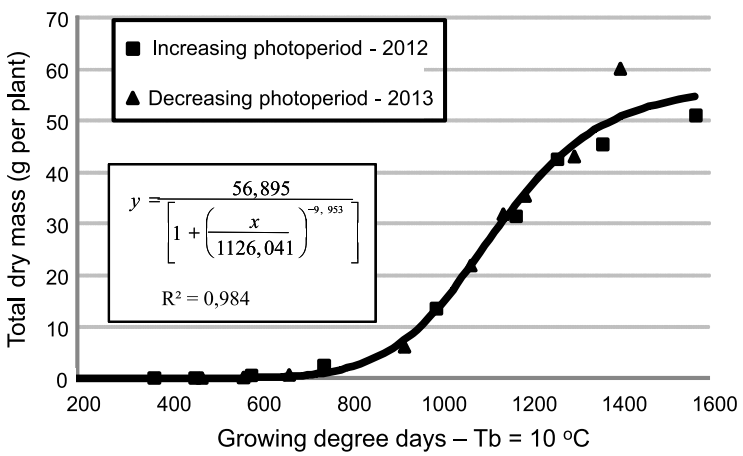

Figure 4 - Accumulated total dry mass of honey weed (Leonurus sibiricus), simultaneously in two different growing conditions, adjusted to accumulated growing degree days, calculated with base temperature of $10{ }^{\circ} \mathrm{C}$. Machado, MG, 2013.

the occurrence of exponential growth stage after $700 \mathrm{GD}$; and the blooming around 1,400 GD (Figure 4).

The flow and length of the photosynthetically active radiation, the availability of nutrients and water, the loss of photosynthetic tissue and, without a doubt, the photoperiod may also affect the vegetal growth and development (Russelle et al., 1984; Gramig $\&$ Stoltenberg, 2007). The thorough analysis of the data enables the assumption that neither days nor thermal units, by means of $\mathrm{GD}$, were adequate to estimate the general phenology of honey weed during all four seasons of the year (Figure 2). The most rapid development of the species took place during the increasing photoperiod, with blooming 100 days after sowing. On the other hand, the weight accumulation could be adjusted to thermal units, $\mathrm{Tb}=10^{\circ} \mathrm{C}$ (Figure 4). Therefore, it is possible to note a major environmental influence on the species' phenology and a minor influence on the growth (weight accumulation), where other variables may, potentially, complement the mathematical models.

\section{ACKNOWLEDGEMENTS}

The authors would like to thank Instituto Federal de Educação, Ciência e Tecnologia do Sul de Minas Gerais - IFSULDEMINAS, Campus Machado for the financial support of this study, and especially for the scientific 
initiation scholarship that was granted to the first author.

\section{LITERATURE CITED}

BENINCASA, M. M. P. Análise de crescimento de plantas: noções básicas. Jaboticabal: FUNEP, 2004. 42 p.

BIANCO, S. et al. Estimativa da área foliar de plantas daninhas. XIII - Amaranthus retroflexus L. Ecossistema, v. 20, n. 1, p. 5-9, 1995.

CAO, W.; MOSS, D. N. Temperature and daylength interaction on phyllochron in wheat and barley. Crop Sci., v. 29, n. 4, p. 1046-1048, 1989.

CARVALHO, S. J. P.; LÓPEZ-OVEJERO, R. F.; CHRISTOFFOLETI, P. J. Crescimento e desenvolvimento de cinco espécies de plantas daninhas do gênero Amaranthus. Bragantia, v. 67, n. 2, p. 317-326, 2008.

DIAS, A. C. R.; CARVALHO, S. J. P.; CHRISTOFFOLETI, P. J. Fenologia da trapoeraba como indicador para tolerância ao herbicida glyphosate. Planta Daninha, v. 31, n. 1, p. 185-191, 2013.

DUARTE, M. R.; FERREIRA LOPES, J. Morfoanatomia foliar e caulinar de Leonurus sibiricus L., Lamiaceae. Acta Farm. Bonaerense, v. 24, n. 1, p. 68-74, 2005.

FERREIRA, E. A. et al. Avaliação fitossociológica da comunidade infestante em áreas de transição para o café orgânico. Planta Daninha, v. 29, n. 3, p. 565-576, 2011.

GADIOLI, J. L. et al. Temperatura do ar, rendimento de grãos de milho e caracterização fenológica associada à soma calórica. Sci. Agric., v. 57, n. 3, p. 377-383, 2000.

GHERSA, C. M.; HOLT, J. S. Using phenology prediction in weed management: a review. Weed Res., v. 35, n. 6, p. 461-470, 1995.

GILMORE JR., E. C.; ROGERS, J. S. Heat units as a method of measuring maturity in corn. Agron. J., v. 50, n. 10, p. 611-615, 1958.

GRAMIG, G. G.; STOLTENBERG, D. E. Leaf appearance base temperature and phyllochron for common grass and broadleaf weed species. Weed Technol., v. 21, n. 1, p. 249-254, 2007.

GRANIER, C.; TARDIEU, F. Is thermal time adequate for expressing the effects of temperature on sunflower leaf development? Plant Cell Environ., v. 21, n. 7, p. 695-703, 1998.
GUO, P.; AL-KHATIB, K. Temperature effects on germination and growth of redroot pigweed (Amaranthus retroflexus), Palmer amaranth (A. palmerii), and common waterhemp (A. rudis). Weed Sci., v. 51, n. 6, p. 869-875, 2003.

HESS, M. et al. Use of the extendend BBCH escale - general for descriptions of the growth stages of mono-and dicotyledonous weed species. Weed Res., v. 37, n. 6, p. 433-441, 1997.

HOLT, J. S.; ORKUTT, D. R. Functional relationships of growth and competitiveness in perennial weeds and cotton (Gossypium hirsutum). Weed Sci., v. 39, n. 4, p. 575-584, 1991.

HORAK, M. J.; LOUGHIN, T. M. Growth analysis of four Amaranthus species. Weed Sci., v. 48, n. 3, p. 347-355, 2000.

KIRKBY, E. J. M. Factors affecting rate of leaf emergence in barley and wheat. Crop Sci., v. 35, n. 1, p. 11-19, 1995.

KISSMANN, K. G.; GROTH, D. Plantas infestantes e nocivas. São Paulo: BASF Brasileira, 2000. p. 47-50. Tomo III.

LORENZI, H. Plantas daninhas do Brasil: terrestres, aquáticas, parasitas e tóxicas. 3.ed. Nova Odessa: Instituto Plantarum, 2000. 608 p.

LORENZI, H. Manual de identificação e controle de plantas daninhas: plantio direto e convencional. 6.ed. Nova Odessa: Instituto Plantarum, 2006. 339 p.

LUCCHESI, A. A. Utilização prática de análise de crescimento vegetal. Anais ESALQ, v. 41, n. 1, p. 181-202, 1984.

McLANCHLAN, S. M. et al. Effect of corn induced shading and temperature on rate of leaf appearence in redroot pigweed (Amaranthus retroflexus L.). Weed Sci., v. 41, n. 4, p. 590593, 1993.

MEDEIROS, G. A. et al. Crescimento vegetativo e coeficiente de cultura do feijoeiro relacionados a graus-dia acumulados.

Pesq. Agropec. Bras., v. 35, n. 9, p. 1733-1742, 2000.

RADOSEVICH, S.; HOLT, J. S.; GHERSA, C. Weed ecology: implications for vegetation management. New York: John Willey, 1997. 589 p.

RONCHI, C. P. et al. Acúmulo de nutrientes pelo cafeeiro sob interferência de plantas daninhas. Planta Daninha, v. 21, n. 2, p. 219-227, 2003. 
RUSSELLE, M. P. et al. Growth analysis based on degree days. Crop Sci., v. 24, n. 1, p. 28-32, 1984.

SANDERSON, M. A.; WOLF, D. D. Morphological development of switchgrass in diverse environments. Agron. J., v. 87, n. 5, p. 908-914, 1995.

STREIBIG, J. C. Herbicide bioassay. Weed Res., v. 28, n. 6, p. 479-484, 1988.
VASCONCELOS, G. M. P. V. et al. Determinação da temperatura base $(\mathrm{Tb})$ para estudo da exigência térmica de Digitaria insularis. In: CONGRESSO BRASILEIRO DA CIÊNCIA DAS PLANTAS DANINHAS, 28., Campo Grande, 2012. Resumos Expandidos... Campo Grande: SBCPD, 2012. p. 776-780.

VILLA NOVA, N. A. et al. Modelo para previsão da produtividade do capim elefante em função da temperatura do ar, fotoperíodo e frequência de desfolha. R. Bras. Agrometeorol., v. 7, n. 1, p. 75-79, 1999. 